\title{
Welfare in Danish Dairy Herds 1. Disease Management Routines in 1983 and 1994
}

\author{
By L. Alban and J.F Agger
}

Department of Anımal Science and Anımal Health, Division of Ethology and Health, The Royal Veterinary and Agrıcultural Unıversity, Frederıksberg, Denmark

\begin{abstract}
Alban, L. and J. F. Agger. Welfare in Danish dairy herds 1. Disease management routines in 1983 and 1994. Acta vet. scand. 1996, 37, 49-63. - This paper presents the first part of a questionnaire survey carried out in 2148 Danish dairy herds during 1994, as well as results from a similar survey carried out in 1983 The welfare status in Danish dairy herds with respect to disease management routines currently applied is discussed In detall this was recording of mastitis incidents, use of veterinarian for milk fever cases, farmer's effort in reducing incidence of mastitis, milk fever, ketosis, calving problems, and lameness, as well as frequency of claw trımmıng, reasons for culling, and way of replacing cullings Furthermore, trends during the 11 year period are discussed The results show that the Danısh dairy farmers in 1994 in general have a substantial knowledge of prevention and treatment of disease. However, adjustments in the following areas would be appropriate 1) farmers should avoid making intravenous infusions, 2) they should be encouraged to use calving boxes for parturitions, 3) there should be more attention on claw health, and 4) to comply with the new Danish legislation, antibiotic dry cow treatment should only be carried out on the individual cow if pathogenic microorganısms have been isolated withın 35 days prior to drying off.
\end{abstract}

dairy cow; care; descriptive epidemiology; cattle; animal welfare; farm management; disease prevention; questionnaires; surveys.

\section{Introduction}

During the last decades, the disease pattern among dairy cows has changed from mainly diseases of highly contagious nature to mainly multifactorial production diseases of non-infectious nature or caused by potential pathogens. These diseases cannot be eliminated without major changes in the production system. But if the predisposing factors are not rectified, disease will soon recur. However, this may not be economical feasible, and farmers therefore accept a certain disease level, mainly controlled by treatment and culling. It is widely accepted that management routines are associated with production diseases. There is little evidence, though, on management procedures in general and about their actual impact on disease. It is difficult to obtain valid information about these routines, but one way is by means of questionnaire surveys.

Simonsen (1993) defined welfare to be the sum of positive and negative experiences that an animal has. As examples of substantial negative experiences Simonsen (1993, 1996) stated pain, fear, and frustration, and as examples of substantial positive experiences joy, play, and satisfied expectations. By being associated with pain and discomfort, production diseases like mastitis, milk fever, ketosis, lameness, and re- 
productive disorders are substantial problems that affect the cows' welfare.

The aim of the present paper is to discuss the welfare status and trends in the development in Danish dairy herds in 1994 with respect to currently applied disease management routınes related to dairy cow welfare. Results from a questionnaire survey carried out in 2148 Danish dairy herds in Ringkøbing County, Funen County, and around the city of Brørup in the Southwest of Jutland, as well as results from a 1983 survey are presented. Housing systems, grazing routines and welfare are dealt with in another paper (Alban \& Agger 1996), and health management and other general routines in a third paper (Agger \& Alban 1996).

The present questionnaire survey was carried out as a part of the research project "Welfare in dairy cows" funded by the Danish Ministry of Agriculture.

\section{Materials and methods}

This publication and the publications by Alban \& Agger (1996) and Agger \& Alban (1996) are based on 2 data sets collected in 1983 and in 1994. The results from the 1983 study, which was carried out by the second author, will be given in the text. From the 1994 study the results will primarily be in the tables. The results of the 2 surveys will be compared to each other and to a large survey carried out in 1988 (Anon 1988), and trends during the 11 year period will be discussed. Furthermore, the results of the 1994 survey will be compared to the general recommendations for cattle keeping.

\section{The 1983 study}

A case control study in Danish dairy herds with the aim to identify environment and management risk factors for high somatic cell count $(\geq 500,000$ cells per ml) vs. low somatic cell count $(<500,000$ cells per ml $)$ in bulk tank milk was undertaken in 1983. Data about 282 env1- ronment factors with regard to details in housing design, hygiene, clımate, milking and milking machine were collected by 2 dairy technicians. Information about 400 management variables with regard to herd structure, occurrence of disease, culling procedures, workıng routınes, methods of production control and disease surveillance, drying off and other milking procedures, feeding, working hours and manpower, and personal information was collected at a personal interview with the farmer by one veterinarian. Only information on tie stall herds and variables corresponding to those included in the 1994-study will be presented here.

Due to the case control sampling, estımates for the population parameters were calculated under the assumption that the case herds and control herds were representative for their respective subpopulations with regard to environment and management patterns. The estımates were adjusted for the respective sampling proportions of the case and control herds in the study area, i.e. East Denmark. The total study population included 1659 tie stall dairy herds including 79 case herds and 1580 non case herds identified during a 9 months period. The samples included 75 case herds and 77 of the non cases. The distribution of factor categories in the samples were weighted as follows: Case herds: $79 / 1659=0.05$; Control herds: 1580 / $1659=0.95$. The population estımates were therefore calculated for each variable under study as:

$$
\begin{gathered}
\mathrm{P}_{\text {pop }}\left(\text { category }_{1} \text { of the factor }\right)= \\
\sum(005 \times \text { prob category } \mid \text { case }+ \\
095 \times \text { prob category } \mid \text { control })
\end{gathered}
$$

where. $\quad 1=1,2, \quad, \mathrm{k}$ factor categories.

\section{The 1994 study}

A questionnaire was designed to obtain information on housing, grazıng, work load, replace- 
ment of animals, and prevention, treatment and recording of disease. The questionnaire can be obtained from the authors upon request.

The Danish Agricultural Advisory Center cooperated in the selection of the study herds and provided the names and addresses of the dairy producers. All dairy herds belonged to 1 of the 3 areas: Ringkøbing County, Funen County, or around the city of Brørup in the Southwest of Jutland. The dairy farmers and veterinarians in those regions were the first in Denmark to implement the Central Danısh Disease Recording Scheme. They therefore had most experience with disease recording. The selection criterion was that the herd should have reported a minımum of 0.05 cases of mastitis per cow per year to the Central Danish Disease Recording Scheme. This assured exclusion of herds in which disease recording did not function. Information about disease occurrence was needed since another aim of the study was to investigate the association between disease, housing, management, and production.

An introductory letter was ma1led to the farmers explanıng the purpose of the survey. The letter informed the farmer that he would be contacted by telephone by a student from The Royal Veterınary and Agricultural University and asked questions about the darry herd. A few days later, the farmer was contacted by the student and the interview was carried out. A total of 22 pretrained students conducted the telephone interviews which each lasted 15- 45 min. Initially, a limited test survey was carried out in December 1993 and January 1994 in 65 randomly selected herds in Ringkøbing County and Funen County. All identified errors and misunderstandings were corrected in the final questionnaire. The interviewers were instructed to phrase the questions, exactly as they were written every time they conducted an interview. The interviews were carried out from February to September 1994.

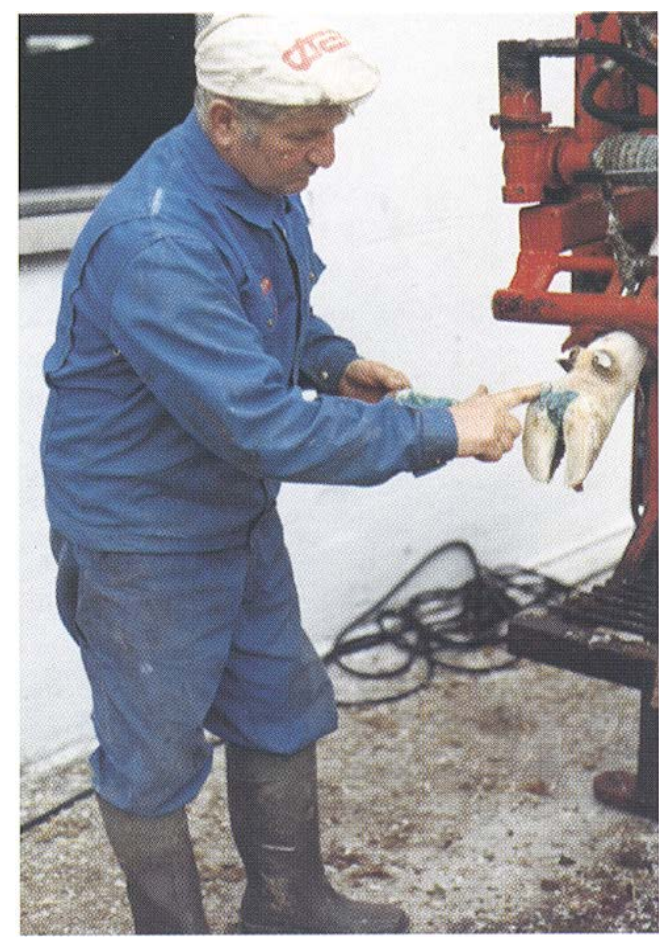

Figure 1 The farmer is applying cuppersulphur ointment on a claw. This is an example of the farmer's effort to prevent or treat lameness

The data were filed as a SAS-dataset (SAS Institute Inc. 1987). All interview forms were controlled for coding errors by visual inspection, and the SAS-data file was then proof read by comparison to the original questionnare forms.

A total of 2391 farmers were contacted, but 57 herds could not be reached by telephone. 186 were contacted but refused to be interviewed. The stated reasons for refusing to participate varied. Some farmers had just sold or were about to sell their cows. A few of the farmers had died, and their wives did not want to participate. Some were too busy or did not speak Danısh. And some did just not like to participate in the survey. Hence, a total of 2148 inter- 
views were carried out, yielding a $89.8 \%$ response rate. This is a high response rate, so the results are considered representative of the population in the 3 areas and very likely to the rest of Denmark. The interviews were performed with the husband in $91.2 \%$ of the herds, with the wife in $5.6 \%$, and with the farm hand in $3.2 \%$ of the herds. A simple cross tabulation showed that the interviews were performed with a person different from the one primarily taking care of the cows in $10.1 \%$ of the herds. This may have lead to a few information biases. All variables were stratified for type of housing because housing is known to impact strongly on management procedures. Fifteen herds with mixed types of cattle houses were excluded from the analysis, i.e. the results are based on 2133 dairy herds. In case there was a significant association between a variable and type of housing, this is stated. In case of no significant association, the tables were collapsed across type of housing. The statistical evaluation was done by use of Chi-square test and Pearson standardized residual analysis (Christensen 1990).

\section{Results}

1983 study

In the 1983 survey in tie stall herds, $35.5 \%$ of the farmers did nothing to prevent mastitis. They only called the veterınarian for therapy. More frequent milking was done by $58.1 \%$, warm soap bath or liniment was applied by $29.5 \%$ of the farmers, and $5.5 \%$ stated that they massaged the udder. $22.9 \%$ of the farmers dipped all cow teats daily, $64.9 \%$ never dipped teats, and $12.2 \%$ dipped infrequently. $8.0 \%$ of the farmers daily dipped the teats of the dry cows. The farmers evaluated the occurrence of lameness on a 9-grade scale. Lameness was seldom (grade 7-9) observed in $80.3 \%$ of the herds, while $7.7 \%$ observed lameness very fre- quently (grade $1-3$ ), and $12.0 \%$ less frequently (grade 5-6). Regarding frequency of trimming, $14.2 \%$ of the herds never had the cows claw trimmed, $50.7 \%$ had all cows trimmed once a year, $9.0 \%$ twice a year, and $21.2 \%$ only had a few cows in need trimmed. The rest used other routines. Regarding dry cow treatment, $43.5 \%$ never used intramammary antibiotic treatment of the dry cows, $53.5 \%$ used selective therapy, and only $2.8 \%$ treated all cows. The 6 major reasons to cull a cow were: low yield $(71.1 \%)$, disease $(66.4 \%)$, not pregnant $(57.3 \%)$, pregnant heifers waiting for space in the cow stall $(40.1 \%)$, age $(16.5 \%)$, and bad temper of cow (15.4\%). Culled cows were replaced by own stock in $75.5 \%$ of the farms, while $12.7 \%$ only bought heifers from other herds or from a market place, and $11.8 \%$ purchased both heifers and cows from outside.

\section{4 study}

In the majority of the farms (88.9\%) all inc1dents of mastitis were apparently reported to the Central Danish Disease Recording Scheme (Table 1). $18.1 \%$ of the farmers would deal with a part or all cases of milk fever in their herd (Table 2). Significantly more deep bed farmers treated more than $50 \%$ of the milk fever cases

Table 1. Number of farmer-observed incidents of mastitis within the past 30 days of the interview which were not reported to the Central Danish Disease Recording Scheme

\begin{tabular}{lrr}
\hline $\begin{array}{l}\text { Number* of incidents which } \\
\text { were not reported }\end{array}$ & No & $\%$ \\
\hline 0 (All incidents reported) & 1897 & 88.9 \\
$1-5$ & 153 & 7.2 \\
$6-10$ & 11 & 05 \\
$>10$ & 2 & 01 \\
Did not answer or did not remember & 70 & 3.3 \\
\hline Total & 2133 & 100 \\
\hline
\end{tabular}

*. the data are not adjusted for herd size. 
Table 2 Use of veterinarian in case of milk fever by the type of housing system.

\begin{tabular}{|c|c|c|c|c|c|c|c|c|}
\hline \multirow{2}{*}{$\begin{array}{l}\text { Proportion of incidents of milk fever } \\
\text { that the farmer would deal with himself }\end{array}$} & \multicolumn{2}{|c|}{ Tre stall house } & \multicolumn{2}{|c|}{ Cubicle house } & \multicolumn{2}{|c|}{ Deep bed house } & \multicolumn{2}{|c|}{ Total } \\
\hline & No & $\%$ & No & $\%$ & No & $\%$ & No & $\%$ \\
\hline The veterinarian deals with all cases & 1546 & 82.5 & 150 & 777 & 43 & 66.2 & 1739 & 81.5 \\
\hline Farmer deals with $<50 \%$ of the cases & 148 & 79 & 18 & 9.3 & 7 & 10.8 & 173 & 8.1 \\
\hline Farmer deals with $50 \%-99 \%$ of the cases & 126 & 6.7 & 19 & 9.8 & $12^{*}$ & 185 & 157 & 7.4 \\
\hline Farmer deals with all cases hımself & 47 & 2.5 & 6 & 3.1 & 3 & 46 & 56 & 2.6 \\
\hline Did not answer & 8 & 0.4 & 0 & 0.0 & 0 & 0.0 & 8 & 0.4 \\
\hline Total & 1875 & 100 & 193 & 100 & 65 & 100 & 2133 & 100 \\
\hline
\end{tabular}

$*: \mathrm{p}<0.001$

themselves compared to tie stall farmers or farmers with cubicle houses $(\mathrm{p}<0.001)$ (Table 2).

The farmers were asked which routines they carried out to prevent or treat 5 different diseases: mastitis (Table 3), milk fever (Table 4), ketosis (Table 5), dystocia (Table 6), and lameness (Table 7). More than 1 answer could be given. The answers to each question are presented as the number of farmers stating the routine, and the percentages are calculated as the number of positive responses divided by the total number of farmers. In this way, the sum of percentages will usually be higher than 100 . Procedures to prevent or treat mastitıs were

Table 3. Mastitis - The farmers' procedures for prevention and treatment.

\begin{tabular}{lrr}
\hline $\begin{array}{l}\text { Farmer's prevention or } \\
\text { treatment procedure }\end{array}$ & No. & $\%^{1}$ \\
\hline Liniment, o1l, soap bath a.o. & 1239 & 58.1 \\
Massage and milking the udder & 724 & 33.9 \\
Disinfection of udder or floor & 488 & 22.9 \\
Prevention against summer mastitis & 16 & 0.8 \\
Used antıbiotics himself & 50 & 2.3 \\
Did nothing or did not answer & 405 & 19.0 \\
\hline
\end{tabular}

${ }^{1}$ Percentages were calculated as the number of positive answers divided by the number of farmers, which was 2133 . commonly used (Table 3 ). To prevent milk fever, oral administration of calcium was commonly used (Table 4). To prevent ketosis (Table 5), tie stall farmers had higher use of glycerol or other glucogenic substances than farmers with the other housing systems. Regarding prevention of dystocia (Table 6), extra litter was used by more tie stall farmers than by farmers with the other types of cattle houses. A straw bale behind the cow at calving was almost only used in tie stall houses. A calving box was used much more frequently in cubicle houses than in the other types of houses.

More farmers with cubicle houses would claw trim the cows compared to farmers with the

Table 4. Milk fever - The farmers' procedures for prevention and treatment.

\begin{tabular}{lrr}
\hline $\begin{array}{l}\text { Farmer's prevention or } \\
\text { treatment procedure }\end{array}$ & No & $\%^{1}$ \\
\hline $\begin{array}{l}\text { Oral administration of calcium } \\
\text { Subcutaneous adm. of calcium and }\end{array}$ & 1510 & 70.8 \\
feedıng strategy & 154 & 7.2 \\
$\begin{array}{l}\text { Intravenous administration of calcium } \\
\text { Did nothing or did not answer }\end{array}$ & 478 & 22.4 \\
\hline${ }^{1}$ Percentages were calculated as the number of pos1- \\
tive answers divided by the number of farmers, \\
which was 2133.
\end{tabular}


Table 5. Ketosis - The farmers' procedures for prevention and treatment of ketosis by the type of housing system.

\begin{tabular}{|c|c|c|c|c|c|c|c|c|}
\hline \multirow{2}{*}{ Farmer's prevention or treatment procedure } & \multicolumn{2}{|c|}{ Tie stall house } & \multicolumn{2}{|c|}{ Cubicle house } & \multicolumn{2}{|c|}{ Deep bed house } & \multicolumn{2}{|c|}{ Total } \\
\hline & No & $\%^{1}$ & No & $\%$ & No & $\%$ & No & $\%$ \\
\hline Glycerol \& glycerol-like substances & $240 *$ & 12.8 & 17 & 8.8 & 3 & 46 & 260 & 12.2 \\
\hline Other glucogenic substances & $511^{*}$ & 27.3 & 28 & 14.5 & 11 & 16.9 & 550 & 25.8 \\
\hline $\begin{array}{l}\text { Feeding strategy, post treatments, } \\
\text { or did not have ketosis }\end{array}$ & 485 & 259 & 56 & 29.0 & 17 & 26.2 & 558 & 26.2 \\
\hline Did not answer & 835 & 44.5 & 105 & 544 & 35 & 53.8 & 975 & 45.7 \\
\hline
\end{tabular}

${ }^{1}$ Percentages were calculated as the number of positive answers divided by the number of farmers. This was 1875 tie stall farmers, 193 cubicle house farmers, and 65 farmers with deep bed house, in total 2133.

*: Apparent difference between housing systems, but not based on a statistical test

Table 6. Dystocia - The farmers' procedures for prevention and treatment by the type of housing system.

\begin{tabular}{|c|c|c|c|c|c|c|c|c|}
\hline \multirow{2}{*}{ Farmer's prevention or treatment procedure } & \multicolumn{2}{|c|}{ T1e stall house } & \multicolumn{2}{|c|}{ Cubicle house } & \multicolumn{2}{|c|}{ Deep bed house } & \multicolumn{2}{|c|}{ Total } \\
\hline & No & $\%^{1}$ & No & $\%$ & No & $\%$ & No & $\%$ \\
\hline Pullıng out or turnıng calf & 1470 & 78.4 & 157 & 81.3 & 47 & 72.3 & 1674 & 785 \\
\hline Use of calving box & 527 & 281 & $123 *$ & 63.7 & 17 & 26.2 & 667 & 31.3 \\
\hline Extra litter for the cow & $591 *$ & 315 & 28 & 145 & 10 & 15.4 & 629 & 29.5 \\
\hline $\begin{array}{l}\text { Wooden platform or straw bale } \\
\text { behınd the tethered cow }\end{array}$ & $420 *$ & 22.4 & 3 & 1.6 & 0 & 0.0 & 423 & 198 \\
\hline Use of pullıng machıne & 58 & 3.1 & 3 & 1.6 & 1 & 1.5 & 62 & 2.9 \\
\hline Removal of placenta & 34 & 1.8 & 8 & 4.1 & 1 & 1.5 & 43 & 2.0 \\
\hline Other procedures & 51 & 2.7 & 15 & 7.8 & 2 & 31 & 68 & 3.2 \\
\hline Did nothing or did not answer & 109 & 5.8 & 7 & 3.6 & 2 & 31 & 68 & 32 \\
\hline
\end{tabular}

${ }^{1}$ See foot note of Table 5 .

* Apparent difference between housing systems, but not based on a statistical test.

other housing systems (Table 7). The farmers were asked how many per cent of the cows had been lame during the last year. However, since the farmers' statements are based on memory, these are only rough statements (Table 8). There were more "no-cases" among tie stall herds than among the other types of cattle houses $(p=0.01)$, while the cubicle house herds had a higher proportion $(\mathrm{p}<0.001)$ and the tie stall herds a lower proportion $(p=0.018)$ of herds with frequent incidents of lameness. Only in $4.3 \%$ of the herds was claw trimming seldom or never carried out (Table 9). Cows in zero- grazing herds were claw trimmed more often than cows in summer grazing herds $(p<0.014)$ (Table 10). A total of $75.6 \%$ of the farmers had all cows trimmed whenever they called the claw trimmer, and $21.8 \%$ only trimmed those with problems or those that had calved recently. In all 3 housing systems dry cow therapy was commonly used for selected cows. More cubicle house farmers $(p<0.001)$ used dry cow therapy for all cows than farmers with the other housing systems (Table 11). The farmers were asked about the most common reasons to cull a cow. Each farmer could give several answers. 
Table 7. Lameness - The farmers' procedures for prevention and treatment by the type of housing system

\begin{tabular}{|c|c|c|c|c|c|c|c|c|}
\hline \multirow{2}{*}{ Farmer's prevention or treatment procedure } & \multicolumn{2}{|c|}{ Tre stall house } & \multicolumn{2}{|c|}{ Cubicle house } & \multicolumn{2}{|c|}{ Deep bed house } & \multicolumn{2}{|c|}{ Total } \\
\hline & No & $\%^{1}$ & No & $\%$ & No & $\%$ & No & $\%$ \\
\hline Call the ferrier & 840 & 44.8 & 68 & 35.2 & 19 & 29.2 & 927 & 43.5 \\
\hline Farmer might trım the claws hımself & 307 & 16.4 & $79 *$ & 40.9 & 15 & 231 & 401 & 18.8 \\
\hline Linıment, oil or soap bath & 155 & 83 & 13 & 67 & 3 & 4.6 & 171 & 8.0 \\
\hline Soft bedding or other procedures & 78 & 4.2 & 19 & 9.8 & 4 & 6.2 & 101 & 4.7 \\
\hline Did nothing or did not answer & 638 & 34.0 & 43 & 22.3 & 30 & 46.2 & 711 & 33.3 \\
\hline
\end{tabular}

${ }^{1}$ See foot note of Table 5 .

* Aparrent difference between housing system, but not based on a statistical test.

Table 8. Incidence risk of lameness during the last year at the herd level by the type of housing system

\begin{tabular}{|c|c|c|c|c|c|c|c|c|}
\hline \multirow{2}{*}{ Incidence risk of lameness } & \multicolumn{2}{|c|}{ Tie stall house } & \multicolumn{2}{|c|}{ Cubicle house } & \multicolumn{2}{|c|}{ Deep bed house } & \multicolumn{2}{|c|}{ Total } \\
\hline & No & $\%$ & No & $\%$ & No & $\%$ & No & $\%$ \\
\hline No cases in the herd & $645^{*}$ & 34.4 & 17 & 8.8 & 8 & 123 & 670 & 31.4 \\
\hline Infrequent $(0 \%<\times<5 \%)$ & 582 & 310 & 53 & 275 & 27 & 41.5 & 662 & 31.0 \\
\hline Frequent $(5 \% \leq x \leq 20 \%)$ & $579^{*}$ & 309 & $111^{*}$ & 575 & 28 & 43.1 & 718 & 33.7 \\
\hline Widespread $(>20 \%)$ & 51 & 27 & 10 & 52 & 2 & 3.1 & 63 & 3.0 \\
\hline Could not remember or did not answer & 18 & 1.0 & 2 & 1.0 & 0 & 0.0 & 20 & 0.9 \\
\hline Total & 1875 & 100 & 193 & 100 & 65 & 100 & 2133 & 100 \\
\hline
\end{tabular}

$*$. $\mathrm{p} \leq 0.018$

(Table 12). There was a substantial difference for lameness as a reason for culling: highest among farms with cubicle houses, next-highest among tie stall farms, and lowest among farms with deep bed houses. Significantly more farmers with deep bed houses would buy a part of or all animals from outside than farmers from the other housing systems $(p<0.001)$ (Table 13).

\section{Discussion}

\section{Recording of mastitis}

Apparently, the majority of mastitis incidents was reported in 1994 (Table 1). Many other diseases are probably not recorded as eagerly. The withdrawal tıme of the milk from a cow treated with antibiotics, and the penalty for a farmer who delivers milk with antıbiotic residues, may be reasons why mastitis probably is one of the diseases which is being recorded most reliably. A reliable disease recording is important for causal research, e.g. for the purposes of sire selection in breeding programmes, and for the veterinarian's advice in herd health management.

Table 9. Frequency of claw trimming.

\begin{tabular}{lrr}
\hline Claw trimmings per year & No & $\%$ \\
\hline Seldom or never & 91 & 43 \\
$1-<2$ & 730 & 34.2 \\
$2-<3$ & 912 & 428 \\
$3-<4$ & 112 & 5.3 \\
4 & 50 & 23 \\
Not specified & 238 & 11.2 \\
\hline Total & 2133 & 100 \\
\hline
\end{tabular}


Table 10. Frequency of claw trimming in zero-grazıng herds and summer grazıng herds Only herds, which reported that the majority $(\geq 60 \%)$ of the cows were trımmed at each trimming, were included.

\begin{tabular}{|c|c|c|c|c|c|c|}
\hline \multirow{2}{*}{ Claw trımmıngs per year } & \multicolumn{2}{|c|}{ Summer grazıng } & \multicolumn{2}{|c|}{ Zero-grazıng } & \multicolumn{2}{|c|}{ Total } \\
\hline & No & $\%$ & No & $\%$ & No & $\%$ \\
\hline Seldom or never & 16 & 15 & 1 & 0.3 & 17 & 1.2 \\
\hline $1-<2$ & $502 *$ & 46.8 & $73 *$ & 21.5 & 575 & 407 \\
\hline $2-<3$ & $489 *$ & 456 & $225^{*}$ & 66.2 & 714 & 506 \\
\hline $3-<4$ & $39 *$ & 3.6 & $34^{*}$ & 10.0 & 73 & 52 \\
\hline 4 & 9 & 0.8 & 6 & 18 & 15 & 11 \\
\hline Not specified & 17 & 16 & 1 & 0.3 & 18 & 13 \\
\hline Total & 1072 & 100 & 340 & 100 & 1412 & $\overline{100}$ \\
\hline
\end{tabular}

$*: p \leq 0014$.

Table 11. Pattern of intramammary dry cow therapy by the type of housing system.

\begin{tabular}{|c|c|c|c|c|c|c|c|c|}
\hline \multirow{2}{*}{ Dry cow therapy } & \multicolumn{2}{|c|}{ T1e stall house } & \multicolumn{2}{|c|}{ Cubicle house } & \multicolumn{2}{|c|}{ Deep bed house } & \multicolumn{2}{|c|}{ Total } \\
\hline & No & $\%$ & No & $\%$ & No & $\%$ & No & $\%$ \\
\hline Never & 311 & 16.6 & 34 & 17.6 & 17 & 262 & 362 & 17.0 \\
\hline A few, $<40 \%$ & 1239 & 66.1 & 109 & 56.5 & 37 & 569 & 1385 & 64.9 \\
\hline Several, $40 \% \leq x<67 \%$ & 103 & 5.5 & 9 & 4.7 & 2 & 3.1 & 114 & 5.3 \\
\hline All cows $\geqslant 67 \%$ & 220 & 117 & $41^{*}$ & 212 & 9 & 139 & 270 & 12.7 \\
\hline Did not answer & 2 & 01 & 0 & 0.0 & 0 & 00 & 2 & 01 \\
\hline Total & 1875 & 100 & 193 & 100 & 65 & 100 & 2133 & $\overline{100}$ \\
\hline
\end{tabular}

$*: \mathrm{p} \leq 0.001$.

Table 12 Distribution of farmers' reasons for culling a cow by the type of housing system

\begin{tabular}{|c|c|c|c|c|c|c|c|c|}
\hline \multirow{2}{*}{ Reasons for cullıng a cow } & \multicolumn{2}{|c|}{ Tie stall house } & \multicolumn{2}{|c|}{ Cubicle house } & \multicolumn{2}{|c|}{ Deep bed house } & \multicolumn{2}{|c|}{ Total } \\
\hline & No & $\%^{1}$ & No & $\%$ & No & $\%$ & No & $\%$ \\
\hline Udder-diseases & 1186 & 63.6 & 123 & 63.7 & 32 & 50.0 & 1341 & 632 \\
\hline Reproduction problems & 1053 & 56.5 & 82 & 42.5 & 32 & 50.0 & 1167 & 550 \\
\hline Low yield & 747 & 40.1 & 97 & 50.3 & 36 & 56.3 & 880 & 41.5 \\
\hline High somatic cell count & 392 & 21.0 & 41 & 21.2 & 12 & 18.8 & 445 & 21.0 \\
\hline Lameness & 292 & 157 & $57 *$ & 29.5 & 3 & 4.7 & 352 & 166 \\
\hline Age & 180 & 9.7 & 21 & 10.9 & 8 & 12.5 & 209 & 9.8 \\
\hline Other diseases & 70 & 3.8 & 9 & 4.7 & 5 & 7.8 & 84 & 4.0 \\
\hline Temperament & 67 & 3.6 & 8 & 4.1 & 1 & 1.6 & 76 & 3.6 \\
\hline Udder conformation & 43 & 2.3 & 3 & 1.6 & 1 & 1.6 & 47 & 2.2 \\
\hline Other reasons & 38 & 20 & 7 & 3.6 & 1 & 1.6 & 46 & 22 \\
\hline
\end{tabular}

1 Percentages were calculated as the number of positive answers divided by the number of farmers This was 1865 tie stall farmers, 193 cubicle house farmers, and 64 farmers with deep bed house, in total 2122.

*: Apparent difference between housing systems, but not based on a statistical test. 
Table 13. Sources of replacement anımals by the type of housing system

\begin{tabular}{|c|c|c|c|c|c|c|c|c|}
\hline \multirow{2}{*}{ Farmer replace anımals } & \multicolumn{2}{|c|}{ Tie stall house } & \multicolumn{2}{|c|}{ Cubicle house } & \multicolumn{2}{|c|}{ Deep bed house } & \multicolumn{2}{|c|}{ Total } \\
\hline & No & $\%$ & No & $\%$ & No & $\%$ & No & $\%$ \\
\hline Only from own stock & 1647 & 87.8 & 176 & 91.2 & 50 & 76.9 & 1873 & 878 \\
\hline Both from own stock and through buying & 180 & 96 & 15 & 7.8 & 9 & 13.8 & 204 & 96 \\
\hline Only through buying & 48 & 26 & 2 & 10 & $6^{*}$ & 92 & 56 & 2.6 \\
\hline Total & 1875 & 100 & 193 & 100 & 65 & 100 & 2133 & 100 \\
\hline
\end{tabular}

*. $\mathrm{p} \leq 0.001$.

When to call the veterinarian for treatment of milk fever

In one fifth of the 1994 herds, not all cases of milk fever were treated by a veterinarian (Table $2)$. This can probably be explained by the following: a skilled farmer is able to distinguish between a mild and a severe case of milk fever. He may deal with the mild case, and leave the severe to the veterinarian. The relatively high proportion of deep bed farmers who dealt with more than half of the milk fever cases might be explained by generally milder cases of milk fever in deep bed cows, either due to lower level of milk production or due to a better resistance against milk fever, compared to tie stall cows or loose housed cows. It may also be a result of a more common use of preventive measures among these farmers. Finally, grazing may be a confounder, e.g. Gustafson (1993) found that grazing cows were at lower risk of milk fever and recovered sooner than zero-grazed cows.

\section{Farmer's routines to prevent or treat disease}

Mastitis: The high concern for preventing mastitis, which was seen both in the 1983 survey and in the 1994 survey (Table 3), may probably be explained by the withdrawal period for the milk associated with an antibiotic treatment of the udder. Some farmers prefer to deal with the mild cases by use of liniment, oil, soap bath, or milking the udder more frequently, and restrict antibiotic treatment for the more severe cases.
The number of farmers who stated that they applied antibiotics for mastitıs treatment may be higher than the stated $2.3 \%$, because a change in the Danish regulations regarding this subject was expected in 1994. The new law came into act on June 1st, 1995 and permits farmers to do antibiotic follow up treatment after an initial treatment by a veterinarian. In return, the farmer has to enter a formal health agreement including 12 yearly consulting visits to the farm by the veterinarian (Anon. 1995a). From a welfare point of view, the high interest in preventing mastitis is positive.

Milk fever - Milk fever occurs as a result of mineral imbalances, mainly due to too low levels of plasma calcium, and there are several approaches to prevent this, see e.g. Jönsson (1978) and Horst et al. (1994). One approach is oral administration of calcium gel at the time of parturition. This was commonly used by the Danısh farmers in 1994 (Table 4). It is a prolonged, but slow treatment, and which is easily overcome by the farmers. Only $3.7 \%$ of the farmers stated that they infused calcium preparations intravenously. According to the new Danish law on drugs for veterinary use, which came into act on June 1st, 1995, intravenous infusions are now restricted to be used only by the veterinarian (Anon. 1995b). One reason for this is that severe tissue damage may occur if the infusion is not carried out properly, and if the cal- 
cium preparation is given too quickly, heart block may occur (Phillips 1982). Hence, infusions should be given by skilled personel.

Ketosis - Ketosis is a disease usually related to the feeding of cows (Baird et al. 1974, Baird $1982, E d d y$ 1992). It was therefore interesting to note that one quarter of the 1994 farmers stated that they never had ketosis or that they prevented it through feeding (Table 5). Administration of glycerol and other glucogenic substances were also commonly used to prevent ketosis. Tie stall farmers had the highest use of glycerol or other glucogenic substances, and this may be explained by a better opportunity to administer a drug to a tied cow compared to a not-tied cow. Another explanation is that loose housed cows might have a reduced incidence of ketosis compared to tied cows (Ekesbo 1966, Bendixen et al. 1987). From a welfare point of view, prevention must be the optimal situation.

Dystocia - Calving boxes were only commonly used in the cubicle houses (Table 6). The use of a calving box may give a more relaxed parturition and a better start in life for the newborn calf. But the farmer has to give colostrum to the newborn calf since a calving box in itself does not assure this (Jonasen \& Krohn 1991; Edwards 1982). The cow goes through a metabolic change at parturition, which may predispose it to several diseases, among these milk fever, ketosis, lameness, cystic ovaries, and mastitis. A calving box providing free movement may reduce the risk of the cow developing disease, e.g. Krohn et al. (1990) found that leaving the calf with the cow for 5 days resulted in a 2-2.5 times lower incidence of mastitis. They also found that "the cow's physical behaviour was more normal when the cow and calf were together". At current, the National Committee on Danısh Cattle Husbandry works on a set up of recommendations regarding cattle keeping. Regarding parturitions during the housing season, the temporary recommendation is to separate calving anımals from the other animals, i.e. by use of a calving box, at the latest two days before parturition (Thøgersen, 1995). Use of a pulling machine was not very common in 1994. According to the Danish law it is prohibited to use a pulling machine to assist in parturition, unless, as recommended by the Danish Veterinary Health Board, the pulling capacity is less than $165 \mathrm{~kg}$, which equals the weight of 2 persons (Paulsen 1994).

Lameness - Routines to prevent or treat lameness were not commonly used (Table 7). The low effort seen may be interpreted as a low interest in lameness from the farmers in general. Another explanation is that many cases of lameness have a silent onset which makes diagnosing difficult. A third explanation is that only few farmers have a claw trimming box which is almost essential in case the farmer wants to trim the claws himself. The larger proportion of cubicle farmers who would claw trim themselves may be related to the presence of extra personel on these farms (Agger \& Alban 1996). The proportion of 1994 farmers who stated that they would trim the claws themselves is twice the number of what was found in a similar study in 1981 (Anon. 1982) and in the 1983 survey. This may be explained by an increasing interest in prevention of lameness among some farmers. Presuming the farmer is acquainted with proper claw trimming, there should be no welfare implication in his claw trimming of own animals. From a welfare point of view, attention on claw health is important, since the majority of claw diseases, are associated with substantial pain or discomfort and are of long duration, and hence, have a large impact on the affected animals' welfare. 
Incidence of lameness during the last year

It is not possible to compare directly to the results of the 1983 survey because another grading was used in the 1983 survey compared to the 1994 survey. The lameness incidence seen in the 1994 survey (Table 8) is higher than the results of a survey made in 1981 where no cases were seen in $11 \%$ of the herds, $75 \%$ had cases infrequently, and $13 \%$ had cases frequently (Anon. 1982). The same range of percentages were used in both surveys: infrequent was equal to $0 \%<x<5 \%$, and frequent $5 \% \leq x \leq 20 \%$. In the 1994 survey, the tie stall herds stated the lowest, and the cubicle herds the highest frequency of lameness. This is somewhat in agreement with Frankena et al. (1992 \& 1993) who found that calves in deep bed houses had the lowest incidence of sole haemorrhages and dermatitis interdigitalis, and calves in tie stall houses second-lowest, compared to calves kept on slatted floors. Rowlands et al. (1983) found that cows in deep bed houses had lowest incidence of lameness and cows in tie stall houses second-lowest, compared to cubicle housed cows. The difference between the present study and the studies by Frankena et al. and Rowlands et al. may be related to confounding factors like breed and herd size. Again, it should be mentioned that lameness has a major impact on the affected animals' welfare. Therefore, in herds with a high incidence of lameness, the causal mechanisms should be investigated and means to reduce the incidence should be taken.

\section{Claw trimming}

In a survey from $1988,13 \%$ of the farmers seldom or never had the cows claw trimmed. $38 \%$ used trimming once a year, and $49 \%$ used trimming more than once a year (Anon. 1988). The difference between the 3 surveys may indicate that the farmers were more aware of claw trimming in 1994 as compared to 1983 , but no change has probably taken place since 1988 .
Claw trimming reduces the number of clinical cases of lameness (e.g. Manson \& Leaver 1989). It seems like the Danish dairy farmers are aware of this beneficial effect, since only a few farmers seldom or never had the cows claw trimmed (Table 9). Analysis for the association between trimming frequency and grazing procedure shows that claw trimming was carried out more often in zero-grazıng herds than in summer grazing herds (Table 10). This confirms that cows wear their claws when grazing. Claws need trimming, but the wear and growth depend on several factors such as breed, level of milk yield, whether the cows graze (and if they graze, the hardness of the field), hardness of stall floor, and presence of rubber mats. Blowey (1993) and Toussiant Raven (1985) recommended that all claws should be examined and the neccessary claws trimmed at drying off. This may reduce the risk of the cow developing lameness after parturition. Toussiant Raven (1985) also recommended claw trimming in the autumn as a preparation for the housing period.

\section{Antiblotic treatment at drying off}

Use of intramammary antibiotic treatment of all dry cows was not common in 1994 (Table 11). However, the response also indicates that it was common to do selective treatment. In the 1988 survey approxımately $50 \%$ of the herds either used selective treatment or treated all cows at drying off. Hence, since 1983 it has become more common to use antibiotic dry cow treatment in tie stall houses and probably also in the other housing systems. The relatively high use of dry cow treatment for all cows which was seen in the cubicle farms cannot be explained directly and has to be investigated further. According to the new Danish law on drugs for veterinary use, antibiotic dry cow treatment on the individual cow should only be carried out in case pathogenic microorganisms have been isolated within 35 days prior to drying off (Anon. 
1995b). The intention of this part of the law is to restrict the preventive use of antibiotics, and hence, to minimize the development of antibiotic resistence and occurrence of drug residues in meat and milk.

\section{Reasons to cull a cow}

Table 12 should be read with the fact in mind that diseases interrelate. Diseased claws may e.g. result in teat tramp, and when the farmer decides which cow to cull, he may only notice the teat tramp and not the lameness that provoked the teat tramp. However, Agger (1981) did not find any clear association between claw lesions and teat lesions. The difference between the tie stall house and the loose house regarding the importance of lameness as a reason for culling was also seen by Krogh Hansen (1986). But Krogh Hansen did not distinguish between deep bed houses and cubicle houses, most likely because deep bed houses were not common in Denmark in 1986. Christensen et al. (1984) found, in a Danish study lasting from 19721980 , that the most common reasons for culling were (listed after order of importance): reproduction, low yield, udder-related problems, and lameness. Dohoo \& Martin (1984) and MilianSuazo et al. (1988) also found that the most common reasons for culling were low yield, reproduction problems and udder-diseases. It seems like udder-diseases have a greater impact in the Danish herds today, compared to the 1970s and 1980s. This might be a result of the increase in average yearly milk yield that has occurred in the same period. The average milk yield for a Danish Holstein-Friesian cow was $5528 \mathrm{~kg}$ in 1980 and $7245 \mathrm{~kg}$ in 1992 - an increase of $31 \%$ (Klejs Hansen 1993).

\section{Replacement of animals}

In general, buying animals was not common in 1994 (Table 13). The deep bed house herds had the highest proportion of farmers who bought a part or all replacement animals. This may be explained by the fact that the deep bed house is a relatively new housing system in Denmark. Hence, some of these farmers may have started their farms recently and had no other possibillity to get new animals than purchasing. Buyıng a heifer or a cow from a market or directly from another farm is always associated with a risk of introducing disease to the herd, e.g. Bovine Virus Diarrhoea or Paratuberculosis. As an example, Agger et al. (1994) found that buying cattle was associated with an increased risk of introducing Streptococcus agalactiae. It seems like the farmers were more aware of the risk of introducing disease into the herd in 1994 compared to 1983.

Advantages with the questionnaire approach Data in epidemiological studies of dairy farm management are often collected by means of an interview or a questionnaire. This is because it is an easy and relatively cheap way of gathering information. Furthermore, a large number of observations can be collected. This may increase the similarity between the study population and the reference population, hence providing a high degree of representativeness.

\section{Problems with the questionnaire approach} Information bias is a general problem with questionnaire data. It may for example occur if the interviewed person gives the answer which he thinks the interviewer would like to hear instead of the truth. To minimize this source of bias, all questions were phrased as value-free as possible. And all interviewers were instructed to phrase the questions neutrally and exactly as written on the interview form. The interviewers could introduce another kind of information bias which is misclassification bias. This would occur if the interviewer misunderstood the farmer. This source of bias was minimized by careful instruction and training of the inter- 
viewers. The repeatability of questionnaire data can be assessed as described by Schukken et al. (1989). It is our intention to repeat the questionnaire in a subsample.

\section{Conclusion}

The results show that the Danish dairy farmers in 1994 in general have a substantial knowledge about prevention and treatment of disease. However, adjustments on the following areas would be appropriate: 1) farmers should avoid making intravenous infusions, 2) they should be encouraged to use calving boxes for partur1tions, 3) there should be more attention on claw health, and 4) to comply with the new Danish legislation, antibiotic dry cow treatment should only be carried out on the individual cow in case pathogenic microorganisms have been 1solated within 35 days prior to dryıng off.

\section{Acknowledgement}

The authors want to thank Annelıse Ito, Christina Ejlersen and Lartey Lawson for excellent technical assistance Carsten Enevoldsen and Thomas Færgeman are acknowledged for instructive comments to the manuscript, and the Danish Agricultural Advisory Center for their cooperation in the project The study was supported by the Danısh Ministry of Agriculture, grant no. VEL92-KVL-8.

\section{References}

Agger JF Pattelæsıon og klovlidelser hos malkekøer (Teat lesion and claw diseases in dairy cows) Ph.D.-thesis, The Royal Veterinary \& Agricultural Unıversity, Frederıksberg, Denmark, 1981, 292 pp.

Agger JF, Alban L Welfare in Danısh Dairy Herds 3. Health Management and General Routınes in 1983 and 1994. Acta vet scand 1996, 37, xxx$\mathrm{xxx}$.

Agger JF, Prou C, Huda A, Aagaard K Risk factors for transmission of Streptococcus agalactiae infection between Danish dairy herds' a case control study Vet Res 1994, 25, 227-234.

Alban L, Agger JF Welfare in Danısh Dairy Herds 2 Housing Systems and Grazing Procedures in
1983 and 1994 Acta vet. scand 1996, 37, xxx$\mathrm{xxx}$

Anon Årsberetnıng 1981 Landsudvalget for Kvæg (Annual Report 1981 The National Committee on Danısh Cattle Husbandry) Århus, Denmark, 1982, p 49.

Anon Produktionssystemer og produktionsmetoder 1 Kvægbruget Landskontoret for Kvæg (Production systems and production methods in the cattle husbandry. The Danısh National Department of Cattle Husbandry) Århus, Denmark, $1988,17 \mathrm{pp}$

Anon Bekendtgørelse om sundhedsrådgivnıngsaftaler for kvæg- og svinebesætnınger Landbrugsministeriet (Regulation on health agreements for cattle and swine herds The Dan1sh Ministry of Agriculture) Regulation No 304, May 11th, 1995a, 8 pp

Anon Bekendtgørelse om lægemıdler tıl veter1nært brug Landbrugsministeriet (Regulation on drugs for veterinary use The Danish Minıstry of Agriculture) Regulation No 303, May 11th, 1995b, 7 pp

Baird GD Primary ketosis in the high-producing darry cow clinical and subclinical disorders, treatment, prevention, and outlook J Dairy Sc1. $1982,65,1-10$

Baird GD, Heltzman RJ, Hibbitt KG, Hunter GD Bovine ketosis a review with recommendations for treatment and control Br. vet J. 1974 Part I, 130, 214-220, and Part II, 130, 318-326.

Bendixen PH, Vilson B, Ekesbo I, Astrand DB Disease Frequencies in Dairy Cows in Sweden IV Ketosis Prev vet Med 1987, 5, 99-109

Blowey $R$ Cattle lameness and hoof care Farming Press London, Great Britain, 1993, 85 pp

Christensen $R$ Loglinear models Springer-Verlag. Berlın, Germany, 1990, 408 pp

Christensen LG, Barlow R, Neimann-Sørensen A Crossbreeding Red Danısh, Holsteın-Friesıan, and Finnish Ayrshire cattle Acta acric scand 1984, 34, 463-479

Dohoo IR, Martın SW Disease, production, and culling in Holstein-Friesian cows, V Survivorship Prev. vet Med 1984, 2, 771-784.

Eddy $R G$ Major Metabolic Disorders. In Andrews AH, Blowey RW, Boyd H, Eddy RG (eds) Bovine Medicine. Blackwell Scientific Publications Oxford, Great Britain, 1992, 577-600

$E d w a r d s S A$ Factors affectıng the tıme to first suckling in dairy calves Anım Prod 1982, 34, 339346 
Ekesbo I Disease Incidence in Tied and Loose Housed Darry Cattle. Acta agric scand. 1966, Suppl 15,79 pp.

Frankena $K$, van Keulen $K A S$, Noordhulzen JP, Noordhuizen-Stassen EN, Gundelach J, de Jong D-J, Saedt I A cross-sectional study into prevalence and risk indicators of digital haemorrhages in female dairy calves. Prev. vet Med. 1992, 14, 1-12.

Frankena $K$, van Keulen $K A S$, Noordhuizen JP, Noordhuizen-Stassen EN, Gundelach J, de Jong $D-J$, Saedt I A cross-sectional study into prevalence and risk indicators of dermatitis interdigitalis in female dairy calves in the Netherlands. Prev vet. Med. 1993, 17, 137-144

Gustafson GM Effects of daily exercise on the health of thed darry cows Prev vet. Med. 1993, 17, 209223

Horst RL, Goff JP, Reinhardt TA Calcium and Vitamin D Metabolism in the Dairy Cow. J. Dairy Sc1 1994, 77, 1936-1951

Jonasen B, Krohn CC Ko-kalv-relationer 4. Adfærd, produktion og sundhed hos pattekalve (SDM) (Cow-calf relations 4. Behaviour, production, and health in sucklercalves (Danısh HolsteinFriesıan)) Report No 689 Natl. Inst Anım. Scı, Denmark, 1991, 43 pp

Jonsson $G$ Milk fever prevention Vet. Rec 1978, 102, 165-169

Klejs Hansen $O$ (ed) Malkekvægets Resultater 1992 Landsudvalget for Kvæg (Results of the dairy cattle production 1992. The National Committee on Danish Cattle Husbandry) Report No 22 Århus, Denmark 1993, 81 pp

Krogh Hansen $B$ Udsætnıng af malkekøer (Cullıng of darry cows). Masters Thesis, The Royal Veterinary \& Agricultural Unıversity, Frederıksberg, Denmark, 1986, p 69.

Krohn CC, Jonasen B, Munksgaard L Ko-kalv-relationer 2 Indflydelse af 0 contra 5 dages patteperiode på koens adfærd, mælkeydelse og yversundhed ved forskellig opstaldning. (Cow-calf relations 2 The effect of 0 versus 5 days suckling on behaviour, milk production, and udder health of cows in different stabling) Report No 678 Natl. Inst Anım Sc1., Denmark, 1990, 20 pp.

Manson FJ, Leaver JD The effect of concentrate: s1lage ratio and of hoof trimming on lameness in dairy cattle. Anım Prod 1989, 49, 15-22

Milian-Suazo F, Erb HN, Smith RD Descriptıve epıdemiology of culling in dairy cows from 34 herds in New York State Prev vet Med 1988, 6, 243251
Paulsen J Dyrebeskyttelse Den Danske Dyrlægeforenıng og Forenıngen tıl Dyrenes Beskyttelse 1 Danmark. (Anımal Protectıon. The Danısh Veterinary Association and The Danısh Anımal Welfare Society). Copenhagen, Denmark. 1994, 388 pp.

Phillips $R W$ Calcium and phosphorus In: Booth NH, McDonald LE (eds) Veterinary Pharmacology and Therapeutics Iowa State University Press Ames, Iowa, USA, 1982, 639-643.

Rowlands GJ, Russell AM, Willams LA Effects of season, herd size, management system, and veterinary practice on the lameness incidence in dairy cattle. Vet Rec. 1983, 113, 441-445

SAS Institute Inc SAS/STAT Guide for personal Computers. Version 6 Edition. SAS Institute Inc. Cary, North Carolına USA 1987, 1028 pp

Schukken YH, van de Geer D, Grommers FJ, Brand $A$ Assessing the repeatability of questionnaire data from dairy farms. Prev vet Med 1989, 7, 31-38

Simonsen $H B$ Vurderıng af dyrs velfærd. I Etık, velfærd og adfærd 1 husdyrbruget. Landbrugets Informationskontor (Assessment of anımals' welfare. In: Ethics, welfare, and behaviour in the anımal husbandry. The Danısh Institute for Agricultural Information) Århus, Denmark, 1993, $17-28$

Stmonsen $H B$ Assessment of animal welfare by a holistic approach Behaviour, health and measured opınion In Sandøe P, Hurnık F (eds ) Welfare of domestic animals concepts, theories and methods of measurement Acta Agric Scand Sect A, Anımal Sc1 1996 Suppl 27, 91-96.

Thøgersen $R$ Integreret kvægproduktion med speciel fokus på sundhed og velfærd (Integrated cattle keeping with emphasis on health and welfare) Proc. from Dansk Boologisk Selskab Denmark, September 1995. II 3 1-II.3 6

Toussaint Raven E Cattle footcare and claw trimming Farming Press Limited Suffolk, Great Britain, 1985, 103-104.

\section{Sammendrag}

Velfard 1 danske kvagbesatninger 1 Sygdomsstyrings-rutiner i 1983 og 1994

Denne artıkel præsenterer første del af et rundspørge udført 12148 danske malkekvægsbesætnınger 11994 samt resultater af en lignende undersøgelse fra 1983 Status og udviklıng gennem de 11 år kommenteres 
for rutıner relateret t1l styrıng af sygdomme, såsom registrerıng af mastıtıs-tılfælde, brug af dyrlæge ved tılfælde af mælkefeber, ejerındsats ved mastıtıs, mælkefeber, ketose, kælvningsproblemer, klovproblemer, hyppighed af klovbeskæring, samt kriterier for udsætnıng og indsætnıng af nye dyr Resultaterne viser, at generelt set har danske mælkeproducenter 11994 en betragtelig viden om forebyggelse og behandling af sygdomme. Æৈndrınger på følgende områder vıl dog være hensıgtsmæssige 1) landmænd bør lkke udføre intravenøse injektioner, 2) landmænd bør opfordres tıl at bruge kælvnıngsboks 1 højere grad, 3) der bør være mere opmærksomhed på klov- og lemmesundhed, og 4) for at overholde den netop ændrede lovgivning bør goldko-behandling med antıbiotıka kun finde sted på den individuelle ko, såfremt patogene mikroorganismer er blevet isoleret indenfor 35 dage før goldnıng.

(Recelved June 30, 1995, accepted November 1, 1995

Reprints may be obtained from L Alban or J.F Agger. Department of Anımal Science and Anımal Health, Division of Ethology and Health. The Royal Veterinary and Agricultural University, Bülowsvej 13, DK-1870 Frederıksberg C, Denmark E-mall JFA@KVL DK, Fax: +45 35283022. 